ARTICLE

https://doi.org/10.1057/s41599-019-0243-8

\title{
What drives people to believe in Zika conspiracy theories?
}

Casey A. Klofstad ${ }^{1}$, Joseph E. Uscinski ${ }^{1}$, Jennifer M. Connolly ${ }^{1} \&$ Jonathan P. West ${ }^{1}$

\begin{abstract}
Conspiracy theories and other pseudo-scientific claims about the Zika virus have been prominent on social media. To what extent are the public concerned about the virus, and to what extent have the public adopted Zika conspiracy theories? Using data from the 2016 Cooperative Congressional Election Study, we show that a majority of Americans are not concerned about the Zika virus, but approximately one in five Americans believes in at least one Zika-related conspiracy theory. The most widely believed is that the virus is caused by genetically modified mosquitoes. We find that elevated levels of conspiracy thinking are correlated with both concern over Zika and belief in Zika-related conspiracy theories. For example, a person scoring the maximum on the conspiratorial thinking scale is estimated to believe in .61 Zika conspiracy theories while a person scoring the minimum is estimated to believe in only .06 Zika conspiracy theories. This study demonstrates the role of predispositions, specifically underlying conspiracy thinking, in the acceptance of conspiratorial and unscientific beliefs.
\end{abstract}

\footnotetext{
${ }_{1}^{1}$ Political Science Department, University of Miami, 1300 Campo Sano Ave., Coral Gables, FL 33146, USA. Correspondence and requests for materials should be addressed to J.E.U. (email: uscinski@miami.edu)
} 


\section{Introduction}

- he Zika virus is spread primarily through the bite of an infected mosquito, but it can also be sexually transmitted (Campos et al., 2015). Infection during pregnancy could cause birth defects, including microcephaly (Nunes et al., 2016). Protecting public health depends on people electing vaccination (when available) and engaging in other precautions to limit transmission.

Instead of relying on authoritative sources, such as the World Health Organization, which states that Zika is a naturally occurring virus, many people have trafficked in conspiracy theories to explain Zika (Kadri and Trapp-Petty, 2016; Venkatraman et al., 2016; Bode and Vraga, 2018). A conspiracy theory is an explanation of an event or circumstance that cites as a main causal factor a small group working in secret against the common good (Uscinski and Parent, 2014); these explanations tend to contradict the judgements of epistemological authorities (Levy, 2007). For example, one conspiracy theory claims that the government secretly created and released Zika (Grimm, 2016).

Conspiracy thinking (sometimes called conspiracist ideation) is an underlying worldview that to one degree or another disposes individuals to reject official accounts and accuse powerful actors of collusion (Brotherton et al., 2013; Imhoff and Bruder, 2013; Lewandowsky et al., 2013b; Uscinski et al., 2016). Individuals are distributed along a continuum in regard to the strength of their conspiracy thinking. All else equal, the higher a person is on that continuum, the more likely they will be to accept a specific conspiracy theory. Previous studies have shown that high levels of conspiracy thinking lead individuals to believe in conspiracy theories about elections (Wood, 2016), the media (Uscinski et al., 2016), downed airliners (Nyhan et al., 2016), Jews (Swami, 2012), sports (Carey et al., 2016), and 9/11 (Wood, 2016). Conspiracy thinking is also associated with the rejection of scientific findings (Marietta and Barker, 2018, Lewandowsky et al., 2013a).

We note that underlying conspiracy thinking and beliefs in specific conspiracy theories are different concepts (Uscinski et al., 2017); the former is a general predisposition while the latter are specific beliefs about specific theories. The relationship between these two concepts is not unlike the difference between partisanship and beliefs about specific political candidates and issues: partisanship certainly predicts more specific political opinions, but not perfectly, and is different than candidate or issue choice (Zaller, 1992). To wit, those with high levels of conspiracy thinking tend not to believe in all conspiracy theories, or in conspiracy theories that contradict their partisanship or other predispositions (Miller et al., 2016; Enders et al., 2018).

The motivating concern for studying the dissemination of Zika conspiracy theories is that such "claims have the potential to become entrenched, increasing the likelihood people will refuse a Zika vaccine" once developed (Dredze et al., 2016). Just mere exposure to an anti-vaccine conspiracy theory can decrease a person's intention to vaccinate (Jolley and Douglas, 2014), and anti-vaccine conspiracy beliefs are difficult to correct (Jolley and Douglas, 2017).

Zika is relatively new and has not been politicized, meaning that studying Zika conspiracy theories gives us the opportunity to learn about how such theories take hold in their early stages. To develop effective communication strategies, practitioners must first understand what people believe (Avery, 2017), and why they have adopted those beliefs (e.g., Motta et al., 2018). In this study, we examine (1) the extent to which Americans are concerned with Zika, (2) the extent to which unscientific conspiratorial claims about Zika's origins have been accepted in the United States, and (3) the dispositional factors that drive concern over
Zika, the acceptance of specific Zika conspiracy theories, and the acceptance of multiple Zika conspiracy theories. We find that respondents' underlying conspiracy thinking predicts their concern over Zika, their belief in Zika conspiracy theories, and the number of Zika conspiracy theories they believe in. By showing that predispositions both engender and limit belief in Zika conspiracy theories, this study suggests that traditional theories of public opinion (e.g., Zaller, 1992) are applicable to conspiracy beliefs about Zika.

\section{Predictions}

We expect that the biggest driver of concern over Zika, belief in Zika conspiracy theories, and belief in multiple Zika conspiracy theories will be underlying conspiracy thinking. Further, given that conspiracy theorists are prone to believing in multiple (and sometimes contradictory) conspiracy theories about particular events (Wood et al., 2012), we expect that as individuals' underlying conspiracy thinking increases, people will believe multiple Zika conspiracy theories are likely true.

\section{Materials and methods}

Participants and procedures. We use data from the two-wave Cooperative Congressional Election Study (CCES) Survey (Ansolabehere and Schaffner, 2017), which YouGov conducted from September - November 2016. Prior approval to conduct all elements of the survey was granted by the University of Miami Human Subjects Research Office on 09/13/2016 (Protocol \#20120757/MOD00013692). We began with a sample of 1000 respondents in the pre-election wave, however, YouGov was unable to contact 223 of the respondents in the second, postelection wave (this appears unrelated to our variables of interest). Each individual in our sample $(433 \mathrm{~F} / 344 \mathrm{M})$ responded to a series of items measuring their overall concern about Zika, their Zika-related conspiracy beliefs, their level of conspiracy thinking, and their demographic information. The demographic and conspiracy thinking measures derive from the pre-election wave; the measures of concern about Zika and belief in Zika-related conspiracy theories derive from the post-election wave.

Dependent variables. Our dependent variables measure Americans' concern over the Zika virus and belief in Zika-related conspiracy theories. Our first measured concern with a 1-to-5 scaled question that asked: "Zika is a disease that is spread to people primarily through the bite of an infected mosquito. It may also be sexually transmitted. The most common symptoms of Zika are fever, rash, joint pain, and conjunctivitis (red eyes). The symptoms are usually mild, and many people do not know they have been infected. However, Zika infection during pregnancy can cause serious birth defects. How concerned are you about a Zika outbreak in your community? Very concerned, somewhat concerned, neither concerned nor unconcerned, not very concerned, or not at all concerned?" We then asked respondents to indicate whether they agreed with conspiracy theories about the virus: "People have suggested many causes for the emergence of the Zika virus. Which of these do you believe are likely causes?" Responses included:

- Zika is caused by vaccines;

- Zika is caused by genetically modified mosquitos (i.e., "GMMs");

- Zika is being used by governments to sicken or kill people on purpose;

- Zika was created to ruin the 2016 Summer Olympics in Brazil; 
- Zika was created by pharmaceutical companies to create demand for a profitable vaccine or drug to combat the disease;

- Zika is a terrorist attack;

- None of the above are a likely cause of Zika.

We randomized the order these were presented, with the exception of "none of the above" which was at the bottom. We employ as dependent variables responses to each of the above conspiracy theories, "none of the above", and a count measure of the number of conspiracy theories each respondent choose.

Table 1 contains descriptive statistics for these; respondents expressed believing between 0 and 6 Zika conspiracy theories with a mean of .33 and a standard deviation of .81 indicating that most people did not believe in any of the conspiracy theories.

Independent variable of interest. To measure our independent variable of interest, conspiracy thinking, respondents were provided with four statements based upon longstanding measures (McClosky and Chong, 1985; Uscinski et al., 2016) and asked to respond-strongly agree to strongly disagree. With these responses we created a measure of conspiracy thinking using a factor analysis procedure ("factor" in Stata), more specifically the principal-component factor method ("pcf"), to extract a single dimension. The factor we use was the only one with an eigenvalue higher than 1 (2.21), and explained 55 percent of the variance in the responses to the four statements. The factor scores were rescaled to run between 0 and 1 , where higher values indicate higher levels of conspiracy thinking. Each statement and the factor loadings for each are in parentheses: "Much of our lives are being controlled by plots hatched in secret places" (.79), "Even though we live in a democracy, a few people will always run things anyway" (.66), “The people who really 'run' the country, are not known to the voters" (.75), and "Big events like wars, the recent recession, and the outcomes of elections are controlled by small groups of people who are working in secret against the rest of us" (.77).

We validated this measure of conspiracy thinking by comparing it to respondents' answers to other questions about specific conspiratorial beliefs. We asked respondents to select from a list of groups they felt "work in secret against the rest of us." The list included ten groups (i.e., "corporations and the rich"). We expected that if our measure of conspiracy thinking is valid, those higher on the measure will identify more groups. Our data indicate exactly this: our conspiracy thinking measure positively correlates with the number of groups selected $(r=.44, p<.001)$; $14.8 \%$ of respondents at the bottom end of our scale believe that no groups are conspiring while those at the high end (.3\%) believe 10 groups are conspiring. Conspiracy thinking also predicts the denial of anthropogenic climate change $(r=.19, p<.001)$, the official explanation of President Kennedy's assassination $(r=.17, p<.001)$, the official explanation of the $9 / 11$ attacks $(r=.22, p<.001)$, and the safety of genetically modified foods $(r=.14, p<.001)$.

Control variables. The analyses presented in Table 3 include several controls. These were chosen because they are standard controls or because they account for factors that could influence concern over Zika or belief in Zika-specific conspiracy theories. To begin, our models include a standard measure of political partisanship ( 1 = "Strong Democrat," $7=$ "Strong Republican") because partisanship has been suggested as one cause of conspiracy beliefs (Miller et al. 2016). Higher levels of education have been associated with lower levels of conspiracy beliefs; therefore we include a variable accounting for levels of education $(1=$ no high school, $3=$ some college, $6=$ post graduate degree). Because Zika is linked to microcephaly, a disease affecting babies in the

\section{Table 1 Dependent variables}

\begin{tabular}{llllll} 
& N & Mean & Min. & Max. & SD \\
\hline Concern about Zika & 777 & 2.94 & 1 & 5 & 1.24 \\
False Beliefs about Zika & & & & & \\
Vaccines & 777 & .03 & 0 & 1 & .18 \\
GMMs & 777 & .14 & 0 & 1 & .34 \\
Government conspiracy & 777 & .04 & 0 & 1 & .21 \\
Ruin 2016 Olympics & 777 & .01 & 0 & 1 & .12 \\
Big pharma & 777 & .07 & 0 & 1 & .26 \\
Terrorism & 777 & .02 & 0 & 1 & .15 \\
None of the above & 777 & .80 & 0 & 1 & .40 \\
Count of false beliefs & 777 & .33 & 0 & 6 & .81 \\
\hline Note: Sample sizes vary due to missing data & \multicolumn{5}{l}{} \\
\hline
\end{tabular}

womb, an indicator of whether the respondent or "someone close to them" was considering having a child in "the next few years", was included. A variable for sex $(0=$ male, $1=$ female $)$ was also included. While the effects of age on conspiracy beliefs vary by study, age is often found to be a significant predictor of engagement with conspiracy theories (Guess et al. 2019); therefore we include birth year in our models. Religiosity is also often found to predict conspiracy beliefs (Oliver and Wood, 2018), therefore we include the importance of religion in the respondent's life ( $1=$ "not at all important," $4=$ "very important"). Because a lack of trust in government is often associated with conspiracy beliefs (Uscinski and Parent, 2014), we include a five point scale of mistrust in government ranging from low to high. Because Zika is a disease that could potentially require medical treatment, we include an indicator of whether the respondent does not have health insurance as a measure of their vulnerability to disease. In addition, we include the number of cases of Zika reported to the U.S. Center for Disease Control in the respondent's state as of 03/09/2017, and the 0-to-100 Google Trend score on the search term "Zika" in the respondent's state during the month of November 2016 (while the survey was being conducted). These variables provide a rough account of the respondents' proximity to reported cases and the relative interest in the disease in their area. Table 2 provides the descriptive statistics for the control variables in this analysis.

Statistical analysis. The survey respondent is the unit of analysis. All analyses were conducted using Stata/SE (version 14.2). The data were weighted using a measure provided by YouGov. Ordered probit models were used for ordinal dependent variables (i.e., the 1-to-5 scaled question that asked about the respondent's concern about the Zika virus), probit models were used for dichotomous dependent variables (i.e., whether the respondent believed in each Zika conspiracy theory), and negative binomial models were used for variables indicative of a count (i.e., the number of Zika conspiracy theories held by the respondent).

\section{Results}

We begin by addressing concern over Zika. Over 40 percent of Americans are "somewhat" or "very" concerned (Fig. 1). Nearly one in five Americans believed at least one of the six Zika conspiracy theories in the questionnaire, (Fig. 2). Close to 14 percent of respondents blame Zika on genetically modified mosquitos, 7 percent believe that the virus was developed by pharmaceutical companies to increase profits, and close to 5 percent believe that Zika was created by the government to "sicken or kill people." Aggregating these responses into a count of the total number of 


\section{Table 2 Independent variables}

Conspiracy thinking

Partisanship (Democrat-Republican)

Education (low-high)

Planning on having a child $(0=$ no, $1=$ yes $)$

Female $(0=$ no, $1=$ yes $)$

Birth year (older-younger)

Importance of religion (low-high)

Health insurance ( $0=$ has, $1=$ does not have)

Number of Zika cases in state (low-high)

Google Trends on "zika" in state (low-high)

Mistrust in government (low-high)

$\begin{array}{ll}1000 & .59 \\ 968 & 3.64 \\ 1000 & 3.21 \\ 777 & .25 \\ 1000 & .52 \\ 1000 & 1968.57 \\ 1000 & 2.77 \\ 1000 & .11 \\ 998 & 268.05 \\ 998 & 52.62 \\ 1000 & 3.36\end{array}$

0
1
1
0
0
1926.00
1
0
3
25
1

20

2.12

1.53

.25

.50

17.84

1.16

.31

350.17

19.87

1.10

Note: Sample sizes vary due to missing data

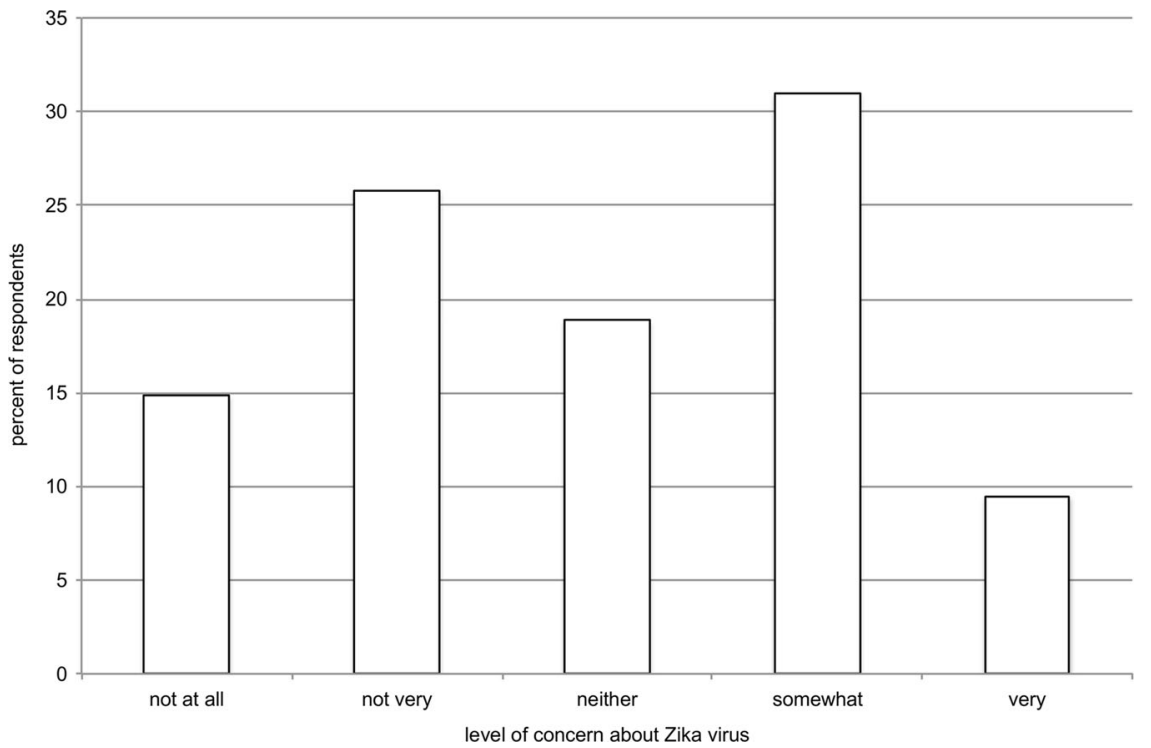

Fig. 1 Concern over Zika. Percentage of respondents expressing levels of concern over Zika Virus

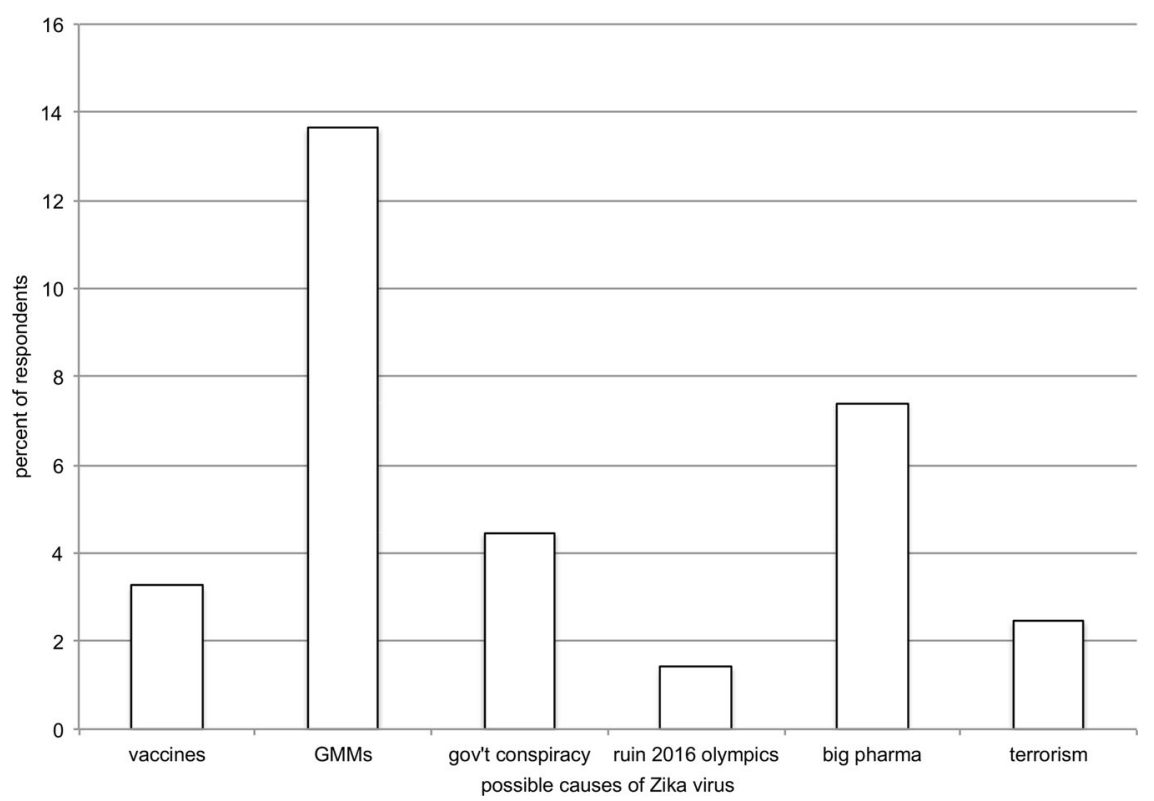

Fig. 2 Belief in Zika Conspiracy Theories. Percent of respondents expressing belief in conspiracy theories about origins of Zika Virus 
Table 3 Correlates of public opinion on Zika virus (multivariate regression analyses)

\begin{tabular}{|c|c|c|c|c|c|c|c|c|c|}
\hline & \multirow[b]{2}{*}{$\begin{array}{l}\text { (1) Concern about } \\
\text { Zika }^{\mathrm{a}}\end{array}$} & \multicolumn{8}{|c|}{ False beliefs about sources of Zika virus } \\
\hline & & $\begin{array}{l}\text { (2) } \\
\text { vaccines }^{b}\end{array}$ & (3) $G M M s^{b}$ & $\begin{array}{l}\text { (4) gov't } \\
\text { conspiracyb }\end{array}$ & $\begin{array}{l}\text { (5) ruin } 2016 \\
\text { Olympics }^{b}\end{array}$ & $\begin{array}{l}\text { (6) big } \\
\text { pharmab }\end{array}$ & $\begin{array}{l}(7) \\
\text { terrorismb }\end{array}$ & $\begin{array}{l}\text { (8) none of the } \\
\text { above }^{b}\end{array}$ & $\begin{array}{l}\text { (9) count of false } \\
\text { beliefs }^{c}\end{array}$ \\
\hline Conspiracy thinking & $.59^{\star \star}(.21)$ & $\begin{array}{l}1.32^{\star} \\
(.66)\end{array}$ & $1.05^{\star \star}(.39)$ & $2.16^{\star \star \star}(.52)$ & $1.50^{\star \star \star}(.46)$ & $1.66^{\star \star \star}(.42)$ & $1.13^{\star \star}(.36)$ & $-1.51^{\star \star \star}(.38)$ & $2.35^{\star \star \star}(.54)$ \\
\hline $\begin{array}{l}\text { Partisanship (Democrat - } \\
\text { Republican) }\end{array}$ & $-.07^{\star \star \star}(.02)$ & $.05(.07)$ & $-.01(.04)$ & $-.01(.05)$ & $-.001(.08)$ & $-.07(.06)$ & $-.09(.08)$ & $.03(.04)$ & $-.05(.07)$ \\
\hline Education (low - high) & $-.04(.03)$ & $\begin{array}{l}-.09 \\
(.08)\end{array}$ & $-.07(.07)$ & $-.04(.06)$ & $-.11(.10)$ & $-.06(.07)$ & $-.11(.06)$ & $.06(.06)$ & $-.13(.08)$ \\
\hline $\begin{array}{l}\text { Planning on having a child }(0=\text { no, } \\
1=\text { yes) }\end{array}$ & $.03(.09)$ & $\begin{array}{l}-.03 \\
(.29)\end{array}$ & $-.16(.19)$ & $.66^{\star \star}(.21)$ & $.14(.29)$ & $-.02(.23)$ & $.26(.30)$ & $-.01(.17)$ & $.11(.29)$ \\
\hline Female $(0=$ no, $1=$ yes $)$ & $.19^{\star}(.08)$ & $\begin{array}{l}-.20 \\
(.28)\end{array}$ & $.04(.16)$ & $.03(.21)$ & $.26(.34)$ & $.10(.21)$ & $-.27(.28)$ & $-.07(.15)$ & $.11(.23)$ \\
\hline Birth year (older - younger) & $-.003(.002)$ & $\begin{array}{l}.04^{\star \star \star} \\
(.01)\end{array}$ & $.02^{\star}(.01)$ & $.02^{\star \star \star}(.01)$ & $.01^{\star}(.006)$ & $.02^{\star \star}(.008)$ & $\begin{array}{l}.02^{\star} \\
(.009)\end{array}$ & $-.02^{\star \star}(.006)$ & $.03^{\star \star \star}(.009)$ \\
\hline Importance of religion (low - high) & $.13^{\star \star \star}(.04)$ & $.12(.11)$ & $.03(.08)$ & $.14(.09)$ & $.05(.13)$ & $.12(.07)$ & $.06(.11)$ & $-.09(.08)$ & $.11(.12)$ \\
\hline $\begin{array}{l}\text { Health insurance }(0=\text { has, } 1= \\
\text { does not have) }\end{array}$ & $-.05(.16)$ & $\begin{array}{l}-.08 \\
(.55)\end{array}$ & $.29(.36)$ & $-.07(.31)$ & - & $.01(.34)$ & - & $-.27(.33)$ & $.08(.38)$ \\
\hline $\begin{array}{l}\text { Number of Zika cases in state (low } \\
\text { - high) }\end{array}$ & $.0004^{\star}(.0001)$ & $\begin{array}{l}.0002 \\
(.001)\end{array}$ & $\begin{array}{l}-.0004 \\
(.0003)\end{array}$ & $-.0001(.0004)$ & $-.0002(.001)$ & $\begin{array}{l}.0005 \\
(.0005)\end{array}$ & $\begin{array}{l}.0005 \\
(.0008)\end{array}$ & $-.00001(.0003)$ & $-.0002(.001)$ \\
\hline $\begin{array}{l}\text { Google Trends on "zika" in state } \\
\text { (low - high) }\end{array}$ & $-.001(.003)$ & $\begin{array}{l}-.002 \\
(.01)\end{array}$ & $.01(.01)$ & $.01(.01)$ & $.01(.01)$ & $-.01(.01)$ & $-.02(.02)$ & $-.001(.006)$ & $.006(.01)$ \\
\hline $\begin{array}{l}\text { Mistrust in government (low - } \\
\text { high) }\end{array}$ & $-.18^{\star \star \star}(.04)$ & $-.01(.11)$ & $-.19^{*}(.08)$ & $.20(.10)$ & $-.35^{\star}(.15)$ & $.12(.08)$ & $.06(.13)$ & $.17^{*}(.07)$ & $-.07(.10)$ \\
\hline Log likelihood & -1116.26 & -82.58 & -268.13 & -96.86 & -42.67 & -160.85 & -67.44 & -319.29 & -478.39 \\
\hline$x^{2}$ & $80.93^{\star \star \star}$ & $27.67^{\star \star}$ & $33.41^{\star \star \star}$ & $51.42^{\star \star \star}$ & $37.90^{\star \star \star}$ & $41.60^{\star \star \star}$ & $29.19^{\star \star}$ & $43.16^{\star \star \star}$ & $50.06^{\star \star \star}$ \\
\hline Pseudo $R^{2}$ & .04 & .22 & .09 & .21 & .19 & .15 & .18 & .11 & .07 \\
\hline$N$ & 755 & 755 & 755 & 755 & 703 & 755 & 703 & 755 & 755 \\
\hline
\end{tabular}

Standard errors in parentheses. Sample sizes vary across models due to listwise deletion of cases with missing data. In Models 5 and 7 having insurance perfectly predicts not believing in the "Olympics" and "terrorism" conspiracies (i.e., perfect collinearity). As such, these cases are dropped from the analysis, and the "no insurance" coefficient is not estimated

${ }^{\star} p \leq .05 ;{ }^{\star \star} p \leq .01 ;{ }^{\star \star \star} p \leq .001$

$p \leq .05 ;{ }^{*} p \leq .01 ;$
Model type: a ordinal probit, brobit, ${ }^{c}$ negative binomial

conspiracy theories indicated, $20 \%$ of respondents believe at least one; $7 \%$ believe more than one.

Results of multivariate analysis. Starting with Table 3 Column 1, the data show that concern about Zika is first and foremost associated with conspiracy thinking, but also to a lesser degree with political partisanship, sex, religiosity, the number of documented Zika cases in the survey respondent's state, and mistrust in government. The predicted probability of a person who scores the maximum on the conspiracy thinking scale being very concerned about the virus is .12 compared to only .04 for a person who scores the minimum on the scale.

The remaining columns of Table 2 indicate that belief in Zika conspiracy theories is largely associated with conspiracy thinking and to a lesser degree with age. Conspiracy thinking is a significant predictor of belief in each of the individual conspiracy theories (Table 3, Columns 2-7). The substantive magnitude of these relationships is presented visually in Fig. 3. Conspiracy thinking is also a significant predictor, albeit negatively, of accepting none of the Zika falsehoods (Table 3, Column 8). Based on the summary count of the total number of conspiracy theories that respondents reported believing in (Table 3, Column 9), a person scoring the maximum on the conspiratorial thinking scale is estimated to believe in .61 conspiracy theories about Zika compared to only .06 for a person scoring the minimum (Fig. 4). Addressing our measure of age, a 49-year-old (the sample mean) is estimated to believe in .27 falsehoods compared to .72 for an 18-year-old (the sample minimum).

\section{Discussion}

This study is one of the first examining Zika conspiracy theories to focus on predispositions-specifically conspiracy thinkingrather than on the availability of misinformation. By showing that conspiracy thinking predicts whether individuals believe in Zikarelated conspiracy theories, our results support (1) previous studies showing that people accept conspiracy theories comporting with their predispositions (Uscinski et al., 2016), and (2) traditional theories of public opinion which incorporate predispositions into explanations of opinion formation. For example, in writing about predispositions and opinion, Zaller (1992, p. 22) states that "[citizens] possess a variety of interests, values, and experiences that may greatly affect their willingness to accept-or alternatively, their resolve to resist-persuasive influence." Social scientists have found it very difficult to dissuade people of their conspiracy theories (Nyhan et al., 2013) and our results suggest a reason why: a strong predisposition towards seeing conspiracies is associated with many conspiracy beliefs.

Our findings suggest that researchers interested in stymying the spread of disease related conspiracy theories will need to focus on those with high levels of conspiracy thinking. For example, Berinsky (2015) finds that messages from co-partisan leaders curbed beliefs about death panels in the Patient Protection and Affordable Care Act (ACA). Given this, we suggest that opinion leaders, particularly those in politics, craft messages that denounce the conspiracy theories (about Zika and other diseases) and provide authoritative information to the public. If members of the public hear from trusted sources, they may eschew some of their conspiracy beliefs. Inoculations, which seek to diminish conspiracy beliefs by exposing them as false before people are exposed to them elsewhere may also prevent online conspiracy theories from affecting people. For example, researchers have found that inoculations can reduce beliefs related to later exposure to $9 / 11$, and vaccine conspiracy theories for example (Banas and Miller, 2013; Jolley and Douglas, 2017; Van Der Linden et al., 2017a). Researchers have further shown that inoculating messages can help people develop resistance to fake news and misinformation more generally (Roozenbeek and Van Der Linden, 2018; van der Linden et al., 2017b). Our study suggests that future research into the effectiveness of inoculation messages should account for people's predispositions to better understand how inoculations can best prevent beliefs among those most likely to believe conspiracy theories (i.e., those with high levels of conspiracy thinking.) 


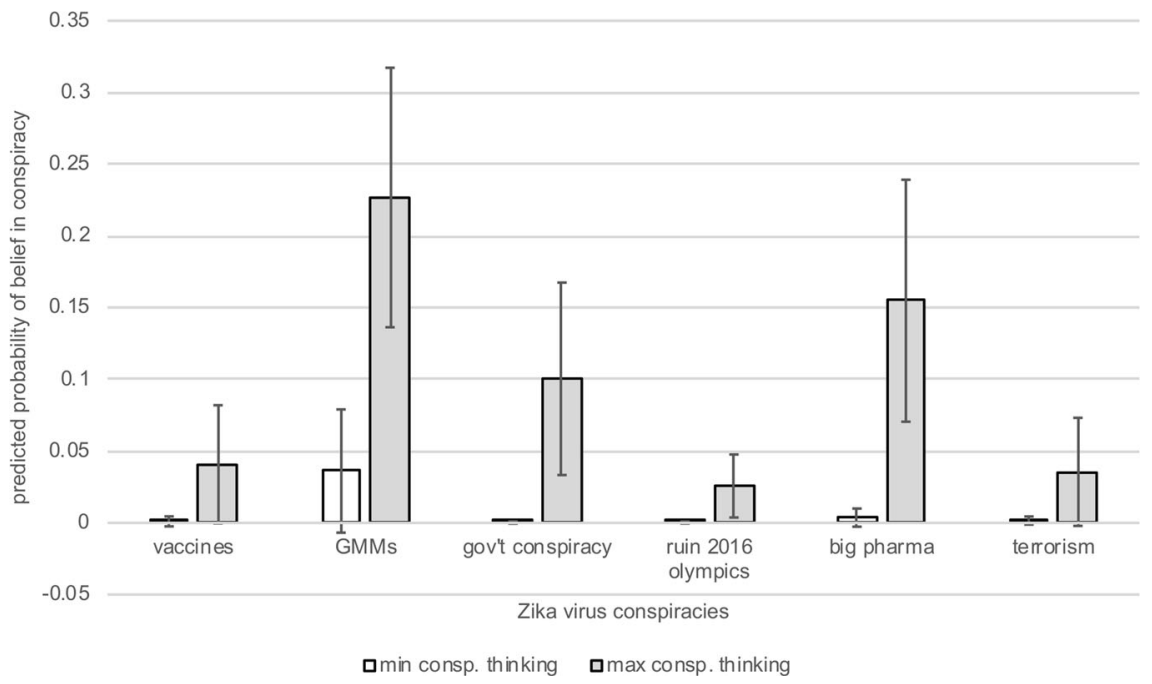

Fig. 3 Effect of Conspiracy Thinking on Belief in Zika Conspiracy Theories. Predicted probability of belief in Zika conspiracy theories by level of conspiracy thinking. Error bars represent $95 \%$ confidence intervals

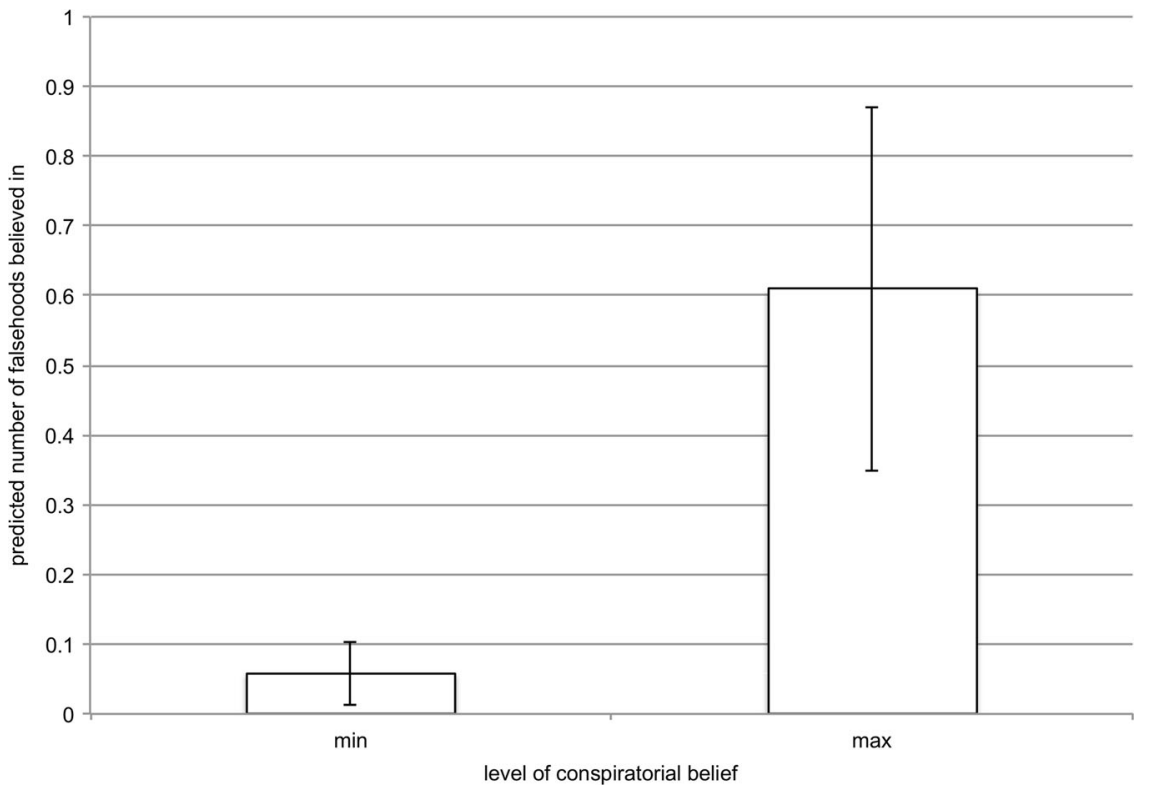

Fig. 4 Effect of Conspiracy Thinking on Belief Summary Count of Zika Conspiracy Theories. Predicted number of Zika conspiracy theories believed in by level of conspiracy thinking. Error bars represent $95 \%$ confidence intervals

Our analysis included multiple demographic and attitudinal variables to be sure that the effect of conspiracy thinking on belief in Zika conspiracy theories was not the result of omitted variable bias. We note that this effect is robust across model specification. None of the control variables show a statistically and substantively significant effect consistently across our models of conspiracy beliefs with the exception of conspiracy thinking and age. Age has a statistically significant impact across our models of conspiracy belief, suggesting that younger people are more likely to agree with the Zika conspiracy theories. While the effect of age on conspiracy beliefs is inconsistent across studies (e.g., Uscinski and Parent, 2014), our finding contradicts recent studies showing that older Americans are the most likely to engage with conspiracy theories on the internet (Grinberg et al. 2019; Guess et al., 2019). Further studies should explicitly study why younger or older Americans might be more likely to believe in specific conspiracy theories. Interestingly, two variables often thought to affect conspiracy beliefs-education and partisanship-show little effect in our models. Education is typically found to be a negative predictor of conspiracy beliefs (Van Prooijen, 2017), but we fail to find a significant effect of education on belief in Zika conspiracy theories. It may be the case that education can in some instances make people more able to adopt and hold onto conspiracy beliefs because their education has made them better at identifying information that matches their dispositions and at defending their beliefs against disconfirming information (Kahan et al., 2012). Partisanship also has little effect in our analysis. This finding contradicts the longstanding view that Republicans are especially prone to conspiracy beliefs (Hofstadter, 1964).

While this study does not specifically examine the effect of social media in spreading Zika conspiracy beliefs, it is clear that Zika conspiracy theories were prominent on social media prior to 
our survey (Dredze et al., 2016). Analysis of Tweets about Zika from 2015-2016 show that Zika conspiracy tweets often invoke supposed experts to suggest a conspiracy, or ask rhetorical questions to cast doubt on official narratives (Wood, 2018). Also, a study of Facebook postings showed that "misleading" posts about Zika were more popular than accurate ones (Sharma et al., 2017) and a study of Twitter documented a "rapid rise in tweets associated with pseudo-scientific claims" about Zika vaccines, even before one was available (Dredze et al., 2016). The available evidence shows that misinformation, particularly conspiracy theories, can travel widely on social media. Our analysis suggests that the people most affected by exposure to those conspiracy theories will be people who already have a strong conspiracy mentality to begin with (see also Uscinski et al., 2016). With this in mind, social media companies interested in stopping the spread of conspiracy theories need to focus on users who exhibit high levels of conspiracy thinking (Bessi et al., 2015) because these are the people who are most likely to fall victim. Altering algorithms so as to not provide a constant stream of conspiracyladen content to conspiracy-minded users might stop some of the spread as well. Educating people about media literacy as it pertains to social media use may prove valuable also (Craft et al., 2017; Kahne and Bowyer, 2017).

Our results also suggest a paradox: Underlying conspiracy thinking drives people to be rightfully concerned about the virus, but also to believe in conspiracy theories, rendering them less likely to combat Zika's spread. As exposure to conspiracy theories can drive (or inhibit) actions (Jolley and Douglas, 2014; van der Linden, 2015), successful public health efforts depend on diminishing the effect of these conspiracy theories. Again, one strategy may be for public officials and science communicators to use inoculating strategies to stymie the spread of conspiracy theories before they take root (Van Der Linden et al., 2017a, 2017b; Roozenbeek and Van Der Linden, 2018; Clayton et al., 2019).

One problem that infectious diseases expose is a widespread distrust of science and scientists (Lewandowsky, 2018; Cullen, 2018). Some people reject scientific consensuses (Pasek, 2018), and underestimate the value of science to society (Vuong, 2018). This often leaves scientists unable to get across accurate information to the public. Improved science education and science communication strategies could overcome the public's doubts about science (Leombruni, 2015; Pearson and Schuldt, 2015; Broniatowski et al., 2016; Avery, 2017), and make people more willing to accept information from experts rather than from alternative unscientific sources.

While our findings move the literature forward, there are several limitations which call for future research. The first limitation is that the study is observational, therefore we cannot be sure that conspiracy thinking is causing Zika beliefs because this study lacks an experimental design. Given this, we rely on the findings of previous experimental studies to infer causal direction (Uscinski et al., 2016), but future studies should employ experimental manipulations to better understand the causal processes at work. Second, this study does not directly measure exposure to online Zika conspiracy theories or directly examine how online conspiracy theories affect beliefs; as such future studies should examine the impact of exposure to online Zika conspiracy theories with experimental designs. Third, this study captures conspiracy beliefs about an emerging disease at one point in time, therefore future studies should attempt to track the dynamism of conspiracy beliefs as they emerge with multiple polls. A research agenda addressing conspiracy beliefs has been developing since 2007 and researchers should begin standardizing survey questions, using panel data to track changes, and polling subgroups to better track conspiracy beliefs.

\section{Data availability}

The datasets analyzed during the current study are available in the Dataverse repository: https://doi.org/10.7910/DVN/UL3SQW.

Received: 20 November 2018 Accepted: 27 February 2019

Published online: 02 April 2019

\section{References}

Ansolabehere S \& Schaffner B (2017) Cooperative Congressional Election Study (CCES) common content. Harvard University, Cambridge, MA, USA. http:// cces.gov.harvard.edu

Avery EJ (2017) Public information officers' social media monitoring during the Zika virus crisis, a global health threat surrounded by public uncertainty. Public Relat Rev 43:468-476

Banas JA, Miller G (2013) Inducing resistance to conspiracy theory propaganda: testing inoculation and metainoculation strategies. Human Commun Res 39:184-207

Berinsky AJ (2015) Rumors and health care reform: experiments in political misinformation. Br J Political Sci 47:241-262

Bessi A, Coletto M, Davidescu GA, Scala A, Caldarelli G, Quattrociocchi W (2015) Science vs conspiracy: collective narratives in the age of misinformation. PLoS ONE 10:e0118093

Bode L, Vraga EK (2018) See something, say something: correction of global health misinformation on social media. Health Commun 33:1131-1140

Broniatowski DA, Hilyard KM, Dredze M (2016) Effective vaccine communication during the disneyland measles outbreak. Vaccine 34:3225-3228

Brotherton R, French CC, Pickering AD (2013) Measuring belief in conspiracy theories: the generic conspiracist beliefs scale. Front Psychol 4:279

Campos GS, Bandeira AC, Sardi SI (2015) Zika virus outbreak, Bahia, Brazil. Emerg Infect Dis 21:1885-1886

Carey JM, Nyhan B, Valentino B, Liu M (2016) An inflated view of the facts? How preferences and predispositions shape conspiracy beliefs about the Deflategate scandal. Res Polit 3:2053168016668671

Clayton K, Blair S, Busam JA, Forstner S, Glance J, Green G, Kawata A, Kovvuri A, Martin J, Morgan E, Sandhu M, Sang R, Scholz-Bright R, Welch AT, Wolff AG, Zhou A \& Nyhan B (2019) Real solutions for fake news? Measuring the effectiveness of general warnings and fact-check tags in reducing belief in false stories on social media. Polit Behav: 1-23. https://doi.org/10.1007/ s11109-019-09533-0

Craft S, Ashley S, Maksl A (2017) News media literacy and conspiracy theory endorsement Commun Public 2:388-401

Cullen JT (2018) Learning about Conspiracy theories: experiences in science and risk communication with the public about the Fukushima Saiichi disaster. In Uscinski JE (ed.) Conspiracy theories and the people who believe them. Oxford University Press, New York, NY

Dredze M, Broniatowski DA, Hilyard KM (2016) Zika vaccine misconceptions: a social media analysis. Vaccine 34:3441-3442

Enders AM, Smallpage SM \& Lupton RN (2018) Are all 'birthers' conspiracy theorists? On the relationship between conspiratorial thinking and political orientations. Br J Polit Sci 1-18. https://doi.org/10.1017/S0007123417000837

Grimm F (2016) Zika spraying spawns an epidemic of conspiracy theories. The Miami Herald

Grinberg N, Joseph K, Friedland L, Swire-Thompson B, Lazer D (2019) Fake news on Twitter during the 2016 U.S. presidential election. Science 363:374-378

Guess A, Nagler J, Tucker J (2019) Less than you think: prevalence and predictors of fake news dissemination on Facebook. Sci Adv 5:eaau4586

Hofstadter R (1964) The paranoid style in American politics, and other essays. Harvard University Press, Cambridge

Imhoff R, Bruder M (2013) Speaking (un-)truth to power: conspiracy mentality as a generalised political attitude. Eur J Personal 28:25-43

Jolley D, Douglas K (2014) The effects of anti-vaccine conspiracy theories on vaccination intentions. PLoS ONE 9:e89177

Jolley D, Douglas KM (2017) Prevention is better than cure: addressing antivaccine conspiracy theories. J Appl Social Psychol 47:459-469

Kadri S, Trapp-Petty M (2016) The Zika virus fight on social media. Arch Clin Microbiol 7:3

Kahan D, Peters E, Wittlin M, Slovic P, Ouellette LL, Braman D, Mandel G (2012) The polarizing impact of science literacy and numeracy on perceived climate change risks. Nat Clim Change 2:732-735

Kahne J, Bowyer B (2017) Educating for democracy in a Partisan age:confronting the challenges of motivated reasoning and misinformation. Am Educ Res J $54: 3-34$

Leombruni LV (2015) How you talk about climate change matters: a communication network perspective on epistemic skepticism and belief strength. Glob Environ Change 35:148-161 
Levy N (2007) Radically socialized knowledge and conspiracy theories. Episteme 4:181-192

Lewandowsky S (2018) In whose hands the future? In: Uscinski JE (ed.) Conspiracy theories and the people who believe them. Oxford University Press, New York, NY

Lewandowsky S, Gignac GE, Oberauer K (2013a) The role of conspiracist ideation and worldviews in predicting rejection of science. PLoS ONE 8: e75637

Lewandowsky S, Oberauer K, Gignac G (2013b) NASA faked the moon landingtherefore (climate) science is a hoax: an anatomy of the motivated rejection of science. Psychol Sci 5:622-633

Marietta M, Barker DC (2018) Conspiratorial thinking and polarized fact perceptions. In: Uscinski JE (ed.) Conspiracy theories and the people who believe them. Oxford University Press, New York, NY

Mcclosky H, Chong D (1985) Similarities and differences between left-wing and right-wing radicals. Br J Political Sci 15:329-363

Miller JM, Saunders KL, Farhart CE (2016) Conspiracy endorsement as motivated reasoning: The moderating roles of political knowledge and trust. Am J Political Sci 60:824-844

Motta M, Callaghan T, Sylvester S (2018) Knowing less but presuming more: Dunning-Kruger effects and the endorsement of anti-vaccine policy attitudes. Soc Sci Med 211:274-281

Nunes ML, Carlini CR, Marinowic D, Neto FK, Fiori HH, Scotta MC, Zanella PLÁ, Soder RB, Da Costa JC (2016) Microcephaly and Zika virus: a clinical and epidemiological analysis of the current outbreak in Brazil. J De Pediatr 92:230-240

Nyhan B, Dickinson F, Dudding S, Dylgjeri E, Neiley E, Pullerits C, Seog M, Simpson A, Szilagyi H, Walmsley C (2016) Classified or coverup? The effect of redactions on belief in conspiracy theories. J Exp Polit Sci 3:109-123

Nyhan B, Reifler J, Ubel PA (2013) The hazards of correcting myths about health care reform. Med care 51:127-132

Oliver JE \& Wood TJ (2018) Enchanted America: how intuition and reason divide our politics, University of Chicago Press, Chicago

Pasek J (2018) Don't trust the scientists! Rejecting the scientific consensus. In: Uscinski JE (ed.) Conspiracy theories and the people who believe them. Oxford University Press, New York, NY

Pearson AR, Schuldt JP (2015) Bridging climate communication divides. Sci Commun 37:805-812

Roozenbeek J \& Van Der Linden S (2018) The fake news game: actively inoculating against the risk of misinformation. J Risk Res 1-11. https://doi.org/10.1080/ 13669877.2018.1443491

Sharma M, Yadav K, Yadav N, Ferdinand KC (2017) Zika virus pandemic: analysis of Facebook as a social media health information platform. Am J Infect Control 45:301-302

Swami V (2012) Social psychological origins of conspiracy theories: the case of the Jewish conspiracy theory in Malaysia. Front Psychol 3:280

Uscinski JE, Douglas K \& Lewandowsky S (2017) Climate change conspiracy theories. In: Oxford Research Encyclopedia of Climate Science, p 1-43. https://doi.org/10.1093/acrefore/9780190228620.013.328

Uscinski JE, Klofstad C, Atkinson M (2016) Why do people believe in conspiracy theories? the role of informational cues and predispositions. Political Res Q 69:57-71

Uscinski JE, Parent JM (2014) American conspiracy theories. Oxford University Press, New York, NY
Van Der Linden S (2015) The conspiracy-effect: Exposure to conspiracy theories (about global warming) decreases pro-social behavior and science acceptance. Personal Individ Differ 87:171-173

Van Der Linden S, Leiserowitz A, Rosenthal S, Maibach E (2017a) Inoculating the public against misinformation about climate change. Glob Chall 1:1600008

Van Der Linden S, Maibach E, Cook J, Leiserowitz A, Lewandowsky S (2017b) Inoculating against misinformation. Science 358:1141-1142

Van Prooijen J-W (2017) Why education predicts decreased belief in conspiracy theories. Appl Cogn Psychol 31:50-58

Venkatraman A, Mukhija D, Kumar N, Nagpal SJS (2016) Zika virus misinformation on the internet. Travel Med Infect Dis 14:421-422

Vuong Q-H (2018) The (ir)rational consideration of the cost of science in transition economies. Nat Human Behav 2:5-5

Wood M, Douglas K, Sutton R (2012) Dead and alive: beliefs in contradictory conspiracy theories. Social Psychol Personal Sci 3:767-773

Wood MJ (2016) Conspiracy suspicions as a proxy for beliefs in conspiracy theories: Implications for theory and measurement. Br J Psychol 108:507-527

Wood MJ (2018) Propagating and debunking conspiracy theories on Twitter during the 2015-2016 Zika virus outbreak. Cyber Behav, Social Netw 21:485-490

Zaller J (1992) The nature and origins of mass opinion. Cambridge University Press, Cambridge, UK

\section{Author contributions}

Conceived and designed the survey questionnaire: CAK, JEU, JMC, JPW. Analyzed the data: CAK. Wrote the paper: JEU, CAK, JMC, JPW.

\section{Additional information}

Competing interests: The authors declare no competing interests.

Reprints and permission information is available online at http://www.nature.com/ reprints

Publisher's note: Springer Nature remains neutral with regard to jurisdictional claims in published maps and institutional affiliations.

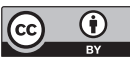

Open Access This article is licensed under a Creative Commons Attribution 4.0 International License, which permits use, sharing, adaptation, distribution and reproduction in any medium or format, as long as you give appropriate credit to the original author(s) and the source, provide a link to the Creative Commons license, and indicate if changes were made. The images or other third party material in this article are included in the article's Creative Commons license, unless indicated otherwise in a credit line to the material. If material is not included in the article's Creative Commons license and your intended use is not permitted by statutory regulation or exceeds the permitted use, you will need to obtain permission directly from the copyright holder. To view a copy of this license, visit http://creativecommons.org/ licenses/by/4.0/.

(C) The Author(s) 2019 